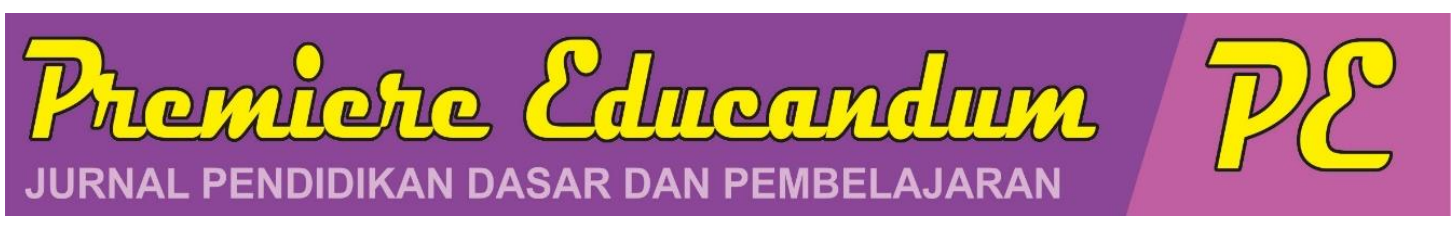

Premiere Educandum: Jurnal Pendidikan Dasar dan Pembelajaran

Volume 9 (2) 160 - 171 Desember 2019

Copyright @2019 Universitas PGRI Madiun

ISSN: 2088-5350 (Print) / ISSN: 2528-5173 (Online)

Available at: http://e-journal.unipma.ac.id/index.php/PE

Doi: $10.25273 /$ pe.v9i2.4994

\title{
Efektivitas ekstrakurikuler pramuka dalam menanamkan karakter jujur disiplin dan bertanggung jawab pada siswa madrasah ibtidaiyah
}

\author{
Ridho Agung Juwantara \\ Program Pascasarjana Pendidikan Guru Madrasah Ibtidaiyah, Fakultas Ilmu \\ Tarbiyah dan Keguruan, UIN Sunan Kalijaga Yogyakarta \\ email: 18204080027@student.uin-suka.ac.id
}

\begin{abstract}
Studying phenomena in madrasah today, many immoral actions appear caused by a lack of student character building. Scouting is an extracurricular activity that can be used to instill good character in students, especially in an honest, discipline, and responsible manner. Scouting values in the form of positive values that are taught and instilled in each student can decorate the attitudes and behaviors of each student who follows them. The purpose of this study is to describe the effectiveness of scout extracurricular activities in instilling character values and observing students' character in taking extracurricular activities. Scouts include three measures of effectiveness, namely the accuracy of program targets, program implementation, and program monitoring. This research is a descriptive research using a qualitative approach. The research subjects included Madrasah Heads, Scout Coaches, Shelter Boards, and the students. The technique of collecting data through interviews, observations, and documentation studies. Data collection tools used are audio video recordings, field notes, and photos. The validity of the data is done by source triangulation and techniques. The results show that scout extracurricular activities are effective in instilling character values. This can be seen from the accuracy of the program targets that have implemented character values, monitoring activities are routinely carried out by Madrasah Heads, Scout Coaches, and Shelter Boards. In addition, monitoring the development of the students can be seen from the results of evaluations and observations of students' attitudes towards a more positive behavior.
\end{abstract}

Keywords: effectiveness, scout extracurricular, students' character.

Abstrak

Mengkaji fenomena di lingkungan madrasah pada dewasa ini, banyak muncul tindakan amoral yang diakibatkan oleh kurangnya pembinaan karakter siswa. Kepramukaan merupakan sebuah ekstrakurikuler yang bisa digunakan untuk menanamkan karakter baik pada siswa, khususnya dalam sikap jujur, disiplin, dan bertanggung jawab. Nilai-nilai kepramukaan yang berbentuk nilai-nilai positif yang diajarkan dan ditanamkan dalam pribadi setiap para siswa dapat menghiasi sikap serta perilaku setiap siswa yang mengikutinya.Tujuan penelitian ini yaitu untuk mendeskripsikan efektivitas ekstrakurikuler pramuka dalam menanamkan nilai karakter serta mengamati karakter siswa dalam mengikuti kegiatan ekstrakurikuler pramuka yang mencakup tiga ukuran efektivitas yakni ketepatan sasaran program, pelaksanaan program, dan pemantauan program. Penelitian ini merupakan penelitian deskriptif dengan menggunakan pendekatan kualitatif. Subjek penelitiannya meliputi Kepala Madrasah, Pembina Pramuka, Dewan Ambalan, dan siswa. Teknik pengumpulan data melalui wawancara, observasi, dan studi dokumentasi. Alat pengumpul data yang digunakan yaitu rekaman audio video, catatan lapangan, dan foto. Keabsahan data dilakukan dengan triangulasi sumber dan teknik.Hasil penelitian menunjukkan kegiatan ekstrakurikuler pramuka efektif dalam menanamkan nilai-nilai karakter. Hal ini dapat dilihat dari ketepatan sasaran program yang sudah menerapkan nilainilai karakter, kegiatan pemantauan secara rutin dilakukan oleh Kepala Madrasah, pembina pramuka, serta dewan ambalan. Selain itu, pemantauan perkembangan siswa dapat dilihat dari hasil evaluasi dan pengamatan sikap siswa kearah yang lebih positif.

Kata kunci: efektivitas, ekstrakurikuler pramuka, karakter siswa

Histori artikel : disubmit pada 25 Agustus 2019; direvisi pada 15 Oktober 2019; diterima pada 24

Oktober 2019 


\section{PENDAHULUAN}

Dalam kehidupan sehari-hari, siswa yang pintar dalam segi kognitif (pengetahuan) namun tidak berkarakter, berkepribadian baik, atau berakhlak mulia justru akan mencelakakan, baik terhadap dirinya sendiri ataupun orang lain. Menurut (Suprayogo, 2013), kepintaran siswa harus diimbangi dengan karakter baik (akhlak mulia). Pendapat ini di dukung oleh Konfisius dalam (A. Kamaruddin, 2012) menurutnya, manusia pada dasarnya memiliki potensi cinta kebajikan, tapi jika tidak didampingi potensi pendidikan dan sosialisasi setelah manusia lahir, maka orang bisa berubah menjadi binatang, bahkan lebih buruk lagi.

Melalui

kegiatan

ekstrakurikuler pramuka, arah pendidikan yang dicita-citakan dapat lebih mudah dicapai. Usaha mendidik dapat ditempuh dengan usaha memanusiakan siswa atau membantu siswa untuk dapat mewujudkan diri sesuai dengan martabat kemanusiaannya (Wahyudin, 2014).

Kepramukaan merupakan

suatu sistem pendidikan kepanduan yang disesuaikan dengan keadaan, kepentingan, dan perkembangan bangsa serta masyarakat Indonesia (Yusup, 2014). Kegiatan kepramukaan (scouting) merupakan sebuah proses pendidikan yang teraplikasi pada kegiatan yang menarik serta menyenangkan bagi anak dengan menggunakan prinsip dan metode khusus. Sasaran dalam pendidikan kepramukaan juga memiliki kekhasan yaitu digunakan untuk meningkatkan karakter yang tidak banyak dimiliki oleh pendidikan non kurikuler lainnya.

Nilai-nilai dalam kepramukaan bersumber dari Tri Satya, Dasadharma, kecakapan, dan keterampilan yang dikuasai anggota pramuka. (Joko Sudrajad, 2010).

Penanaman karakter bukan saja sebagai tanggung jawab orang tua dan masyarakat lingkungan sosial siswa, akan tetapi juga semua pihak, khususnya satuan pendidikan, dalam hal ini tingkat madrasah ibtidaiyah (sekolah dasar) yang sangat diprioritaskan untuk membangun karakter siswa. Ini disiapkan agar ketika menginjak usia remaja siswa yang mempunyai karakter baik atau mempunyai kecerdasan emosi tinggi akan terhindar dari masalah-masalah umum yang dihadapi oleh remaja seperti tawuran, kenakalan, narkoba, miras, perilaku seks bebas, dan sebagainya.

Karakter merupakan watak, tabiat, akhlak, atau keperibadian seseorang yang terbentuk dari hasil internalisasi berbagai kebajikan (virtues) yang diyakini dan digunakan sebagai landasan untuk cara pandang, berfikir, bersikap, dan bertindak (Puskur Balitbang, 2010).

Menurut (Lickona, 2015), karakter yang baik yaitu terdiri dari mengetahui hal yang baik, menginginkan hal yang baik, dan melakukan hal yang baik lalu membiasakannya. Ketiga hal ini diperlukan untuk mengarahkan suatu kehidupan dan membentuk kedewasaan moral. (Lickona, 2013) berpendapat, nilai operatif menuntun 
siswa untuk senantiasa berfikir sebelum bertindak.

Data kemendiknas, menjelaskan ada 18 jenis nilai karakter yang dapat ditanamkan pada anak yaitu Religius, jujur, toleransi, disiplin, kerja keras, kreatif, mandiri, demokratis, rasa ingin tahu, cinta tanah air, semangat kebangsaan, menghargai prestasi, bersahabat/komunikatif, cinta damai, gemar membaca, peduli lingkungan, peduli sosial, tanggung jawab (Yaumi, 2014).

Namun dalam penelitian ini di fokuskan menjadi tiga bentuk karakter yang sering menjadi titik permasalahan sedangkan penerapannya sangat penting di jenjang pendidikan madrasah ibtidaiyah yaitu sikap jujur, disiplin, dan bertanggung jawab.

Hal ini sesuai dengan misi Madrasah Ibtidaiyah Masyariqul Anwar 4 Bandar Lampung, yaitu menciptakan anak didik yang cerdas, memiliki keterampilan, taqwa, dan berakhlak mulia. Di madrasah ini ekstrakurikuler pramuka dilaksanakan oleh siswa kelas V, sebagai kebijakan madrasah melalui beberapa pertimbangan.

Berangkat dari pentingnya penaman karakter yang sudah menjadi komitmen dalam aktualisasi pendidikan nilai sepanjang zaman, penelitian tentang efektivitas pramuka dalam menanamkan karakter siswa sangat menarik untuk dikaji. Ada beberapa penelitian yang berkaitan dengan penelitian ini. Penelitian (Novianti, 2017) tentang pengajaran pendidikan karakter yang difokuskan pada cerita menggunakan Bahasa Inggris Bildungsroman. Hasil penelitian menunjukkan bahwa sebagian besar siswa telah berhasil mengidentifikasi kebajikan dalam novel dan dapat berhubungan dengan karakter mereka. Penelitian tersebut terfokus pada penanaman karakter melalui cerita. Sedangkan penelitian ini difokuskan pada kegiatan ekstrakurikuler pramuka.

Lebih lanjut, penelitian (Tsai, 2012) yang mencermati pendidikan karakter dalam upaya optimalisasi perilaku etis siswa. Hasil penelitian menyajikan definisi, perspektif historis, serta tantangan dan kontroversi di sekolah secara umum. Sedangkan penelitian ini berbasis studi lapangan khususnya di lingkup Madrasah Ibtidaiyah.

Penelitian (Erliani, 2016), tentang gerakan pramuka dalam membentuk karakter kepedulian sosial dan kemandirian. Menurutnya, upaya pembentukan karakter pada Gerakan Pramuka adalah melalui pemahaman, keikhlasan, kerja keras, berjuang dengan sungguh-sungguh,ketaatan, pengorbanan.

Dari beberapa dasar kajian relevan tesebut, tujuan penelitian ini yaitu untuk: a) mengkaji efektivitas pramuka dalam menanamkan nilai karakter; b) mengamati karakter siswa dalam mengikuti kegiatan ekstrakurikuler pramuka yang mencakup tiga ukuran efektivitas yakni ketepatan sasaran program, pelaksanaan program, dan pemantauan program. 


\section{METODE PENELITIAN}

\begin{tabular}{lcr}
\multicolumn{2}{c}{ Penelitian ini } & termasuk \\
penelitian & deskriptif & dengan \\
pendekatan & kualitatif. & Metode ini \\
digunakan & dalam & memahami
\end{tabular}
fenomena yang dialami oleh subyek penelitian seperti perilaku, persepsi, motivasi, tindakan, secara holistik serta dengan cara deskripsi dalam bentuk kata-kata serta bahasa pada suatu konteks khusus yang alamiah dan dengan memanfaatkan berbagai metode alamiah (Moleong, 2015). Menurut (Sugiyono, 2013), metode ini digunakan pada penelitian yang dilakukan pada kondisi yang alamiah serta data yang diperoleh berupa informasi-informasi dan pendapat.

Subjek penelitian ini terdiri dari: a) kepala madrasah sebagai subjek penelitian yang dipilih guna mendapatkan informasi mengenai kebijakan pelaksanaan ekstrakurikuler pramuka; b) pembina pramuka sebagai subjek penelitian yang dipilih guna mendapatkan informasi mengenai perencanaan, pelaksanaan, dan evaluasi kegiatan ekstrakurikuler pramuka; c) pradana pramuka yang merupakan siswa SLTA kelas XI dan XII yang bertugas sebagai dewan ambalan dan membantu pembina pramuka dalam menjalankan tugas. Pradana Pramuka dipilih guna mendapatkan informasi mengenai proses kegiatan; d) siswa sebagai subjek penelitian yang dipilih guna mengetahui nilai karakter yang terdapat pada diri mereka.

Indikator ukuran efektivitas yakni ketepatan sasaran program, pelaksanaan program, dan pemantauan program, secara konkret dapat dilihat pada tabel dibawah ini.

Tabel 1. Indikator Ukuran Efektivitas Pramuka

\begin{tabular}{|c|c|c|}
\hline Indikator & Rincian & Aktualiasasi \\
\hline $\begin{array}{l}\text { Ketepatan Sasaran } \\
\text { Program }\end{array}$ & $\begin{array}{l}\text { - Prinsip dasar } \\
\text { kepramukaan } \\
\text { - } \text { Metode kepramukaan } \\
\text { - Pengamalan trisatya \& } \\
\text { dasadarma } \\
\text { - } \text { Materi kepramukaan }\end{array}$ & $\begin{array}{l}\text { - Integrasi nilai karakter-nilai } \\
\text { kepramukaan } \\
\text { - Pengamalan ilmu } \\
\text { - Pengamalan karakter } \\
\text { - Metode: wawancara }\end{array}$ \\
\hline $\begin{array}{l}\text { Pelaksanaan Program } \\
\text { Kegiatan Pramuka }\end{array}$ & $\begin{array}{l}\text { - Tempat } \\
\text { - Waktu } \\
\text { - Anggota } \\
\text { - Sarana pendukung } \\
\text { - Kegiatan }\end{array}$ & $\begin{array}{l}\text { - Efektivitas kegiatan } \\
\text { - Metode: wawancara dan } \\
\text { observasi }\end{array}$ \\
\hline $\begin{array}{l}\text { Pemantauan Program } \\
\text { Kegiatan Pramuka }\end{array}$ & $\begin{array}{l}\text { - Pemantauan kegiatan } \\
\text { - Pemantauan lembaga }\end{array}$ & $\begin{array}{l}\text { - Evaluasi Ketercapaian } \\
\text { - Metode: wawancara }\end{array}$ \\
\hline
\end{tabular}

Teknik pengumpulan data pada penelitian ini yaitu: a) wawancara mendalam, yang digunakan dalam mengumpulkan keterangan dan merupakan pembantu utama dari pengamatan (Bangun, 2015); b) observasi terbuka, yang tujuannya menggambarkan secara utuh atau 
mampu merekonstruksi proses yang terjadi; c) studi dokumentasi, tujuan untuk mengumpulkan data berupa dokumen baik berupa foto dokumenter, teks/catatan, dan berkasberkas lain yang dapat mendukung pengumpulan data dalam kegiatan tersebut. Teknik analisis data yang digunakan yaitu meliputi reduksi data, penyajian data, dan penarikan kesimpulan atau verifikasi.

Dalam penelitian ini digunakan triangulasi sumber dan triangulasi teknik. Triangulasi sumber digunakan peneliti dalam mengecek data dari berbagai sumber untuk mengetahui kefektifan kegiatan ekstrakurikuler kepramukaan dalam menanamkan nilai karakter jujur, disiplin dan tanggung jawab dengan sumber data utamanya adalah Kepala Madrasah MI Masyariqul Anwar 4 Bandar Lampung. Sedangkan sumber data pendukungnya adalah Pembina Pramuka, Siswa, dan Dewan Ambalan MI Masyariqul Anwar 4 Bandar Lampung yang benar-benar berkompeten dibidang tersebut. Data kemudian di analisis sehingga menghasilkan suatu kesimpulan yang selanjutnya dimintakan kesepakatan dengan sumber-sumber data tersebut. Data dari sumber tersebut kemudian dideskripsikan lalu dikategorisasikan antara pandangan yang sama dengan pandangan yang berbeda.

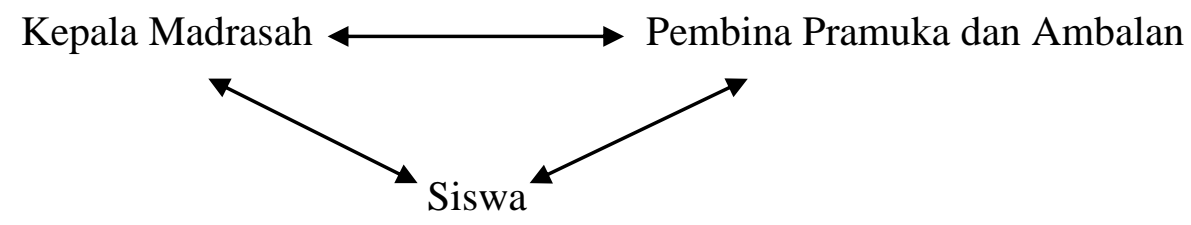

Triangulasi teknik, digunakan peneliti untuk mengecek data dari berbagai teknik pengumpulan data yang digunakan, untuk mengetahui bagaimana efektivitas kegiatan ekstrakurikuler kegiatan kepramukaan dalam menanamkan nilai karakter, dengan teknik pengumpulan data wawancara, observasi dan studi dokumentasi. Bila data yang dihasilkan berbeda-beda, maka peneliti melakukan diskusi lebih lanjut kepada sumber data tambahan untuk memastikan kebenaran datanya.

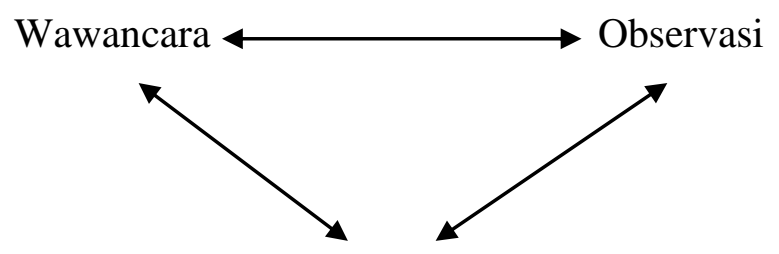

Studi Dokumentasi

Menurut (Marzuki \& Lysa Hapsari, 2015), upaya yang dapat dilakukan untuk pembinaan karakter siswa di lembaga pendidikan di antaranya adalah dengan memaksimalkan kualitas pembelajaran di kelas dan juga kegiatan ekstrakurikuler yang mendukung 
penanaman nilai-nilai karakter siswa di sekolah seperti kegiatan Pramuka.

Berdasarkan uraian diatas, dapat dilihat bahwa karakter siswa dapat dibentuk dan diciptakan melalui pendidikan diluar sekolah (pramuka). Tujuannya yaitu untuk menjadikan siswa yang berakhlakul karimah dengan tertanamnya sikap jujur, disiplin, dan tanggung jawab.
Dalam penelitian ini akan difokuskan pada pelaksanaan kegiatan kepramukaan dan efektivitas kegiatan tersebut dalam menanamkan nilai karakter. Sehingga dapat diketahui keefektifan kegiatan kepramukaan dalam menanamkan nilai karakter siswa kelas V MIS Masyariqul Anwar 4

Bandar

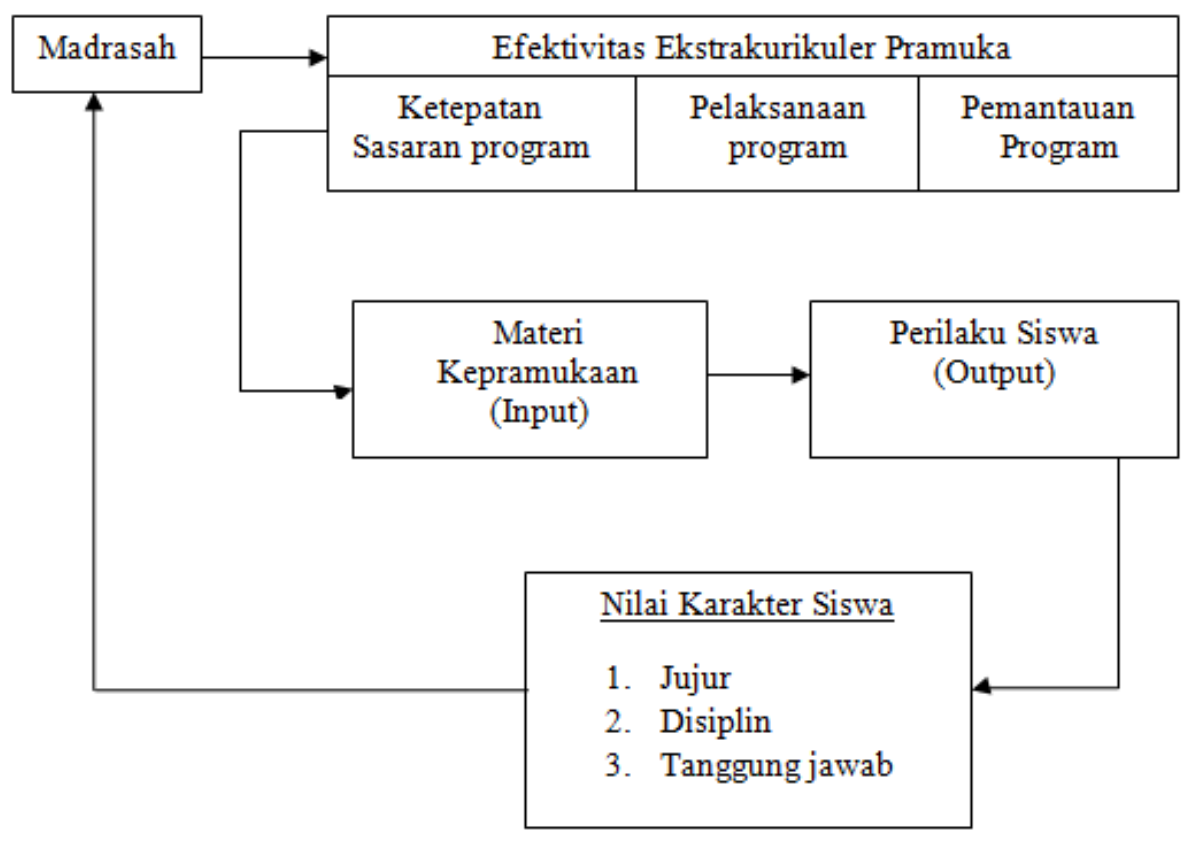

Gambar 1: Alur Penanaman Karakter Melalui Pramuka

\section{HASIL DAN PEMBAHASAN}

Penyajian data hasil penelitian terbagi menjadi tiga kelompok yaitu: Ketepatan sasaran kegiatan, pelaksanaan kegiatan, dan pemantauan program yang akan dijabarkan secara lebih terperinci sebagai berikut:

Ketepatan sasaran program dapat diketahui dengan melihat sejauh Masyariqul Anwar 4 Bandar Lampung dalam menanamkan karakter sudah tercapai dengan baik. Hal tersebut dapat dilihat dari kesesuaian prinsip

\section{Ketepatan Sasaran Kegiatan}

mana program tepat dengan sasaran yang sudah ditentukan sebelumnya. Berdasarkan hasil wawancara dengan kepala madrasah, kegiatan ekstrakurikuler pramuka di Madrasah Ibtidaiyah

dasar pramuka, metode pramuka, serta pengamalan dasadarma dan trisatya yang termaktub dalam materi kepramukaan yang diajarkan di MIS 
Masyariqul Anwar 4 Bandar Lampung sekaligus sudah mencakup nilai-nilai karakter jujur, disiplin dan bertanggung jawab sebagai landasan yang harus dipatuhi.

Menurutnya, Trisatya berisi janji pramuka, sedangkan Dasadarma berisi tentang ketentuan moral pramuka. Dari landasan tersebut sangat tepat jika ekstrakurikuler pramuka dijadikan ekstrakurikuler wajib dalam kurikulum 2013, khususnya pada tingkat pendidikan dasar. Tapi pada penerapannya, pelaksanaan kegiatan ekstrakurikuler pramuka di MIS Masyariqul Anwar 4 Bandar Lampung tidak diwajibkan untuk seluruh siswa, melainkan hanya diwajibkan bagi kelas V saja. Alasan tersebut menurut kepala madrasah selaku pemegang kebijakan tidak ingin terlalu kaku dalam pelaksanaan kepramukaan dengan tetap memperhatikan segala hambatanhambatan yang ada. Contohnya seperti pada siswa kelas I sampai kelas IV, banyak orang tua mereka yang kurang setuju apabila anaknya mengikuti program tambahan kepramukaan, alasannya kasihan dengan fisik anaknya yang menurut mereka masih rentan. Selain itu juga tidak memiliki banyak waktu untuk mengawasi anaknya secara intensif karena kesibukan. Menurut kepala madrasah, untuk siswa kelas VI juga tidak diwajibkan, karena mereka sudah difokuskan untuk persiapan ujian kelulusan. Selain itu siswa kelas VI juga secara otomatis sudah mendapatkan pengalaman kepramukaan dikelas V. Menurutnya, Madrasah memberikan kebijakan penerapan pramuka di kelas $\mathrm{V}$ yang dirasa sangat efektif. Selain penanaman nilai karkakter yang diperoleh dari janji dan ketentuan moral yang diperoleh dari Trisatya dan Dasadarma pramuka, kegiatan kepramukaan di MIS Masyariqul Anwar 4 Bandar Lampung juga sudah berdasarkan pada Prinsip Dasar Kepramukaan dan Metode kepramukaan. Menurut Ambalan yang membantu membina siswa pramuka, program ekstrakurikuler pramuka di MIS Masyariqul Anwar 4 Bandar Lampung sudah mengikuti standar nasional dengan mendidik karakter, fisik serta pengetahuan. Selain itu, para ambalan selalu mempersiapkan materi yang sesuai untuk dilaksanakan praktek pada hari jumat diluar jam belajar siswa. Hal ini efektif karena pada hari jumat waktu pulang sekolah dipercepat untuk solat jumat, sehingga pada siang harinya pembina dan siswa memiliki banyak waktu luang untuk melaksanakan ekstrakurikuler pramuka.

Selanjutnya hasil wawancara dengan Pembina Pramuka diperoleh informasi yaitu, ada beberapa karakter yang secara intensif dipupuk pada diri siswa seperti jujur, disiplin, tanggung jawab dan religius dengan bernuansa nilai-nilai keagamaan yang kuat karena menurutnya itu yang utama. Selain itu, menurut keterangan pembina pramuka juga diadakan rapat koordinasi sebelum kegiatan dilangsungkan, yang bertujuan untuk membahas materi-materi yang akan dilaksanakan pada hari jumat serta untuk menyamakan persepsi. Rapat tersebut dilaksanakan di hari yang 
tidak menentu, tepatnya sebelum hari jumat dengan dihadiri pembina pramuka dan anggota ambalan. Persiapan materi mengacu pada buku pedoman kepramukaan.

\section{Pelaksanaan Kegiatan}

Menurut hasil wawancara dengan pembina pramuka, pada pelaksanaannya kegiatan ekstrakurikuler pramuka di MIS Masyariqul Anwar 4 Bandar Lampung sudah dilaksanakan dengan beberapa metode seperti yang telah tertuang dalam AD ART gerakan pramuka pasal 9 tentang metode kepramukaan yang menjelaskan bentuk kegiatan kepramukaannya dikemas secara menarik, menyenangkan, sehat, teratur, terarah, praktis, di lakukan di dalam kelas maupun alam terbuka dan bertujuan untuk pembentukan karakter. Ekstrakurikuler pramuka MIS Masyariqul Anwar 4 Bandar Lampung sendiri pelaksanaannya di luar jam sekolah yakni dilaksanakan setiap hari jum'at pukul 10.00 sampai dengan selesai atau setelah pelajaran formal di kelas selesai. Bentuk kegiatan yang sudah dilaksanakan di alam terbuka tersebut meliputi kegiatan kemah atau persami hingga outbound. Jadi, kegiatan ekstrakurikuler pramuka MIS Masyariqul Anwar 4 Bandar Lampung tidak hanya terpaku pada materi di dalam kelas saja tetapi juga di lapangan. Untuk menunjang kegiatan menjadi lebih efektif kegiatan ini memiliki fasilitas pendukung diantaranya yakni: tenda pleton, kompas, peta, matras, buku-buku pedoman, kamus pramuka, tongkat, bendera semaphore, bendera pramuka, carabiner (cincin kait), dan tali. Dalam sebuah kegiatan ataupun program tentunya perlu didukung dengan adanya dana. Dana yang digunakan untuk mendanai kegiatan ekstrakurikuler pramuka MIS Masyariqul Anwar 4 Bandar Lampung berasal dari dana BOS. Sementara untuk kurikulum pramuka di MIS Masyariqul Anwar 4 Bandar Lampung telah mengacu pada Kwarnas dan K13. Selain itu, dalam tujuan perkembangan serta inovasi kegiatan kepramukaan tidak hanya diampu oleh pembina yang berafiliasi di madrasah, tetapi juga sering didatangkan narasumber-narasumber dari dewan kerja cabang (DKC) dan dewan kerja ranting (DKR) untuk mengisi kegiatan-kegiatan tertentu seperti pelatihan SKU (syarat kecakapan umum) hingga SKK (syarat kecakapan khusus). Menurut pembina pramuka, pengisian kegiatan tambahan oleh dewan kerja tersebut efektif karena mereka memiliki tugas dan kewajiban mulai dari kajian kepramukaan, evaluasi, pengembangan, hingga pengabdian masyarakat.

Berdasarkan hasil pengamatan di lapangan dan wawancara dengan kepala madrasah, proses penanaman nilai karakter pada pelaksanaan kegiatan pramuka dapat dibuktikan secara efektif dengan tindakan nyata seperti berikut:

a. Tanggung jawab, ditanamkan melalui kegiatan penyampaian materi di dalam kelas dan juga kegiatan di lapangan. Di lapangan terdapat tugas-tugas yang harus dikerjakan siswa pramuka, seperti 
baris-berbaris, menguasai sandi morse dan semaphore, hingga kegiatan menanam pohon. Ini diharapkan agar siswa senantiasa memiliki rasa tanggung jawab terhadap tugas serta dalam menjaga lingkungan. Selain itu, ditanamkan tanggung jawab melalui program sholat jumat bersama. Solat bersama juga menjadi salah satu program yang disusun oleh pembina dan disetujui madrasah serta memanfaatkan fasilitas masjid yang dibangun oleh yayasan. Hal ini juga dapat memupuk rasa tanggung jawab siswa kepada Tuhannya.

b. Jujur, ditanamkan dengan pendampingan secara motivasi. Ini diharapkan agar setiap anggota pramuka dapat dipercaya, terutama terhadap orang lain. Selain itu juga melalui tindakan game kejujuran (temukan anggotamu). Karena dalam game tersebut terdapat nilai kejujuran dan sportivitas. Dalam bermain dituntut kejujuran dan sportivitas. Pemain yang tidak jujur akan mendapatkan sanksi, seperti mendapat hukuman kekalahan.

c. Disiplin, ditanamkan dengan kegiatan apel rutin. Apel pembukaan dan apel penutupan kegiatan pramuka. Nilai-nilai kedisiplinan itu ditanamkan saat akan dilaksanakannya apel. Jadi, pada saat waktu yang sudah ditentukan mereka harus sudah siap di lapangan untuk melaksanakan apel. Kegiatan ini dibimbing oleh pembina dan ambalan. Jadi, ambalan bertugas keliling kelas agar bisa mengkordinir siswa agar tepat waktu sampai lapangan serta mengecek kelengkapan atribut pramuka untuk persiapan apel. Apabila ada dari siswa yang tidak membawa atribut lengkap atau terlambat apel maka akan diberikan hukuman. Dalam hal ini tentunya hukuman yang mendidik agar menjadi pelajaran berharga pada anak dalam membentuk sikap disiplin pada diri siswa serta membiasakan siswa untuk disiplin. Selain itu, efektifitas hasil pelaksanaan kegiatan ekstrakurikuler pramuka dapat dibuktikan dari pengamatan terhadap siswa yang mengikuti pramuka. Didalam proses belajar mengajar aspek jujur siswa dibuktikan dengan berkurangnya mencontek dikalangan siswa hingga mengembalikan barang temuan. Pada aspek disiplin dapat dibuktikan seperti hadir tepat waktu, mematuhi peraturan madrasah dan menggunakan seragam sekolah lengkap. Pada aspek tanggung jawab yaitu seperti mengerjakan tugas sekolah, piket kebersihan sesuai jadwalnya masing-masing, hingga melaksanakan ibadah solat rutin secara berjamaah.

\section{Pemantauan Program Kegiatan}

Berdasarkan keterangan dari kepala madrasah, pemantauan program kegiatan ekstrakurikuler pramuka di MIS masyariqul anwar 4 Bandar Lampung dilaksanakan oleh kepala madrasah, pembina pramuka, ambalan hingga stakeholders. Menurutnya, pemantauan ini dibagi menjadi dua kategori. Pertama, pemantauan dan pengawasan disetiap 
kegiatan rutin. Dalam setiap pelaksanaan kegiatan rutin ekstrakurikuler apapun menurutnya harus selalu ada pengawasan. Artinya para pembina harus selalu hadir. Sekolah mempunyai prinsip yakni, apabila tidak ada guru Pembina maka kegiatan kesiswaan apapun tidak boleh diselenggarakan. Sekolah khawatir dengan adanya ancaman keamanan dan penyalahgunaan baik oleh siswa sendiri atau dari luar jika tidak ada pengawasan. Menurutnya juga, apabila tidak dilakukan pengawasan dari guru pembina nantinya jika terjadi sesuatu yang tidak diinginkan maka yang akan dimintai pertanggungjawabannya adalah madrasah dan yayasan. Selain itu, dalam hal ini kepala madrasah selalu berkoordinasi dengan pembina pramuka sebagai jembatan dalam mengetahui proses berjalannya ekstrakurikuler pramuka. Fungsi dari koordinasi ini yaitu agar dapat memberikan kritik dan saran serta mengetahui fasilitas-fasilitas yang belum dilengkapi dalam menunjang kegiatan. Begitu juga dengan ambalan yang bertugas memantau dalam setiap kegiatan yang berlangsung. Ambalan menjadi orang terdekat siswa ketika dilapangan, memantau, mendampingi, dan memberi arahan ketika siswa perlu diarahkan terkait pelaksanaan kegiatan kepramukaan sehingga kurang dan lebihnya keberlangsungan kegiatan dapat selalu dikoordinasikan dengan pembina.

Kedua, pemantauan program secara kelembagaan. Selain diawasi oleh kepala madrasah, pembina pramuka, serta ambalan. Ada juga pengawasan yang dilakukan oleh stakeholder terkait, mulai dari Kwarcab, Dewan Cabang, hingga rekan-rekan Pembina pramuka di satuan pendidikan lain. Ini dimaksudkan agar fungsi kerjasama dan koordinasi tetap berjalan dalam keberlangsungan kegiatan pramuka di MIS Masyariqul Anwar 4 Bandar Lampung.

\section{PEMBAHASAN}

Meskipun kegiatan pramuka hanya dilaksanakan oleh siswa kelas $\mathrm{V}$ saja, namun hal ini sudah cukup meng generalisasikan kegiatan kepramukaan ini sudah tepat sasaran. Sebab, usia anggota dari pramuka tersebut berkisar antara usia 11-12 tahun yang masuk dalam kategori penggalang dan telah melaksanakan dasar-dasar pramuka sesuai dengan dasar-dasar, metode, prinsip, dan materi yang diberlakukan untuk golongan pramuka penggalang, termasuk pengamalan trisatya dan dasarma oleh siswa. Selain itu, dapat dibuktikan dengan hasil pengamatan peneliti serta rekapitulasi nilai sikap siswa yang tergolong memiliki ratarata baik, yang berbentuk pengamalan ilmu dan karakter di lingkungan sekitarnya sehari-hari.

Dari data pelaksanaan kegiatan diatas, dapat dibuktikan bahwa pelaksanaan kegiatan Pramuka di madrasah juga adalah salah satu media pendidikan yang efektif dalam pengoptimalan otak kanan siswa yang sangat berpengaruh terhadap karakter. Hal ini karena proses pembelajaran di kelas selama ini lebih dominan pada pengembangan otak kiri (IQ: Intelectual Quotient), sementara 
pengembangan otak kanan (EQ: Emotional Quotient) seringkali mendapatkan porsi yang sangat sedikit. Maka dari itu pramuka merupakan kegiatan diluar kelas yang efektif sebagai wahana pengembangan emosional otak kanan, di mana siswa dilatih untuk berinteraksi, berkomunikasi, kreatif, bersikap, dan berafiliasi dengan teman-teman lainnya. Di sinilah kemampuan sosial siswa dibangun, sehingga mampu membekali siswa untuk dapat hidup bersama dengan damai dan harmonis.

Namun, untuk selalu memberikan pengawasan pada perjalanan kegiatan pramuka agar selalu efektif dalam menanamkan karakter, maka dibutuhkan monitoring atau evaluasi yang berkesinambungan dan dilaksanakan baik ketika proses ataupun hasil akhir oleh internal sendiri maupun stakeholder yang kredibel.

\section{SIMPULAN}

Berdasarkan uraian hasil penelitian di atas, dapat disimpulkan: Ketepatan kegiatan ekstrakurikuler pramuka, pelaksanaan kegiatan, hingga pemantauan program yang dimiliki ekstrakurikuler pramuka sudah efektif dalam penanaman karakter. Bentuk aktualisasinya berupa nilai tanggung jawab yang ditanamkan melalui kewajiban penguasaan tugastugas yang diberikan dikelas dan juga kegiatan di lapangan. Jujur ditanamkan dengan pendampingan secara motivasi serta pemberian game (kejujuran). Disiplin ditanamkan dengan kegiatan-kegiatan pembiasaan seperti apel rutin.
Berdasarkan simpulan diatas, peneliti melihat masih minimnya prestasi yang dihasilkan oleh ekstrakurikuler pramuka. Maka dari itu peneliti menyarankan agar pengelolaan kegiatan kepramukaan perlu ditingkatkan, dengan cara memberikan pelatihan yang cukup kepada para pembina serta pemberlakuan pramuka tidak hanya di kelas V saja, sehingga pengalaman siswa lebih optimal dan penanaman karakter lebih efektif.

\section{DAFTAR RUJUKAN}

A. Kamaruddin, S. (2012). Character Education and Students Social Behavior. Journal of Education and Learning (EduLearn), 6(4), 223-230.

https://doi.org/10.11591/edulearn .v6i4.166

Bangun, B. (2015). metodologi Penelitian Kualitatif. Jakarta: Rajawali Pers.

Erliani, S. (2016). Peran Gerakan Pramuka untuk Membentuk Karakter Kepedulian Sosial dan Kemandirian (Studi Kasus di SDIT Ukhwah dan MIS AnNuriyyah 2 Banjarmasin). Mualimuna Jurnal Madrasah Ibtidaiyah, 2(1), 36-46.

Joko Sudrajad. (2010). Hubungan Nilai-nilai Kepramukaan, karakter disiplin dan kerja keras terhadap prestasi belajar siswa mata pelajaran produktif di SMK PGRI 1 Ngawi. 1. Retrieved from https://eprints.uny.ac.id/10059/1/j urnal penelitian.pdf

Lickona, T. (2013). Educating For Character. Jakarta: Bumi Aksara. 
Lickona, T. (2015). Character Matters: Persoalan Karakter, Bagaimana Membantu Anak Mengembangkan Penilaian Yang Baik, Integritas Dan Kebijakan Penting Lainnya. Jakarta: Bumi Aksara.

Marzuki, \& Lysa Hapsari. (2015). Pembentukan Karakter Siswa Kegiatan Kperamukaan Di MAN 1 Yogyakarta. Jurnal Pendiddikan Karakter, V(2), 142-155.

Moleong, L. J. (2015). Metodologi Penelitian Kualitatif. Bandung: Remaja Rosdakarya.

Novianti, N. (2017). Teaching character education to college students using bildungsromans. International Journal of Instruction, 10(4), 255-272. https://doi.org/10.12973/iji.2017. $10415 a$

Puskur Balitbang. (2010).
Pengembangan Pendidikan

Budaya Dan Karakter Bangsa. Jakarta: Depdiknas.

Sugiyono. (2013). Metode Penelitian Kuantitatif, Kualitatif, $R \& D$. Bandung: Alfabeta.

Suprayogo, I. (2013). Pengembangan Pendidikan Karakter. Malang: UIN Maliki Press.

Tsai, K. C. (2012). Bring character education into classroom. European Journal of Educational Research, 1(2), 163-170. https://doi.org/10.12973/eujer.1.2.163

Wahyudin, D. (2014). Pengantar Pendidikan. Jakarta: Universitas Terbuka.

Yaumi, M. (2014). Pendidikan Karakter, Landasan, Pilar, \& Implementasi. Jakarta: Kencana.

Yusup, J. (2014). Panduan Wajib Pramuka. Jakarta: Cmedia. 